\title{
KRONIKA
}

\author{
Forum Pedagogiczne \\ $10(2020) 2$ \\ Wpłynęło: 13.01.2020 \\ Zatwierdzono do druku: 24.06 .2020 \\ DOI: $10.21697 / \mathrm{fp} .2020 .2 .24$
}

DARIUSZ STĘPKOWSKI*

Warszawa, Polska

ORCID ID: https://orcid.org/oooo-0oo2-6855-1517

\section{Sprawozdanie z międzynarodowej konferencji naukowej pt. „Ethics and Education”, Warszawa, 29-30 listopada 2019 roku}

„Ethics and Education” to tytuł cyklu konferencji odbywającego się co dwa lata na Wydziale Pedagogicznym Uniwersytetu Warszawskiego. W roku 2019 była to już piąta edycja tego wydarzenia naukowego. W dwudniowych obradach wzięło udział w sumie 16 naukowców z ośmiu krajów: ośmiu z Polski, dwóch z Hiszpanii i po jednym z Belgii, Holandii, Izraela, Stanów Zjednoczonych, Wielkiej Brytanii i Włoch. Organizatorem konferencji był Rafał Godoń, który jednocześnie pełnił obowiązki gospodarza i moderatora podczas wszystkich sesji.

Obrady zostały podzielone na 10 sesji. Każda sesja składała się z dwóch wystąpień i dyskusji po każdym referacie. Między sesjami odbywały się 15-minutowe przerwy.

Otwarcia konferencji dokonał Rafał Godoń, który w skrócie przypomniał wiodącą ideę warszawskich spotkań - promocję filozofii edukacji w Polsce. Rolę ojców założycieli tejże serii konferencji odgrywają Joanna Górnicka-Kalinowska i z Uniwersytetu Warszawskiego i Stefaan Cuypers z Catholic University w Luwanium, którzy w 2011 roku zorganizowali pierwsze spotkanie.

Po naszkicowaniu programu obrad R. Godoń otworzył pierwszą sesję i poprosił o zabranie głosu keynote speaker - Giuseppinę D’Addelfio z University of Palermo we Włoszech. Tytuł jej referatu brzmiał: The importance of values in education. A phenomenological challenge to the contemporary moral subjectivism. Prelegentka skupiła się na charakterystyce postaci Dietricha von Hildebranda i przedstawieniu jego stanowiska filozoficznego. Jej zdaniem zasługuje on na szczególną uwagę nie tylko $z$ tego powodu, że rozwinął koncepcję stojącą w opozycji wobec Maxa

\footnotetext{
* Dr hab. Dariusz Stępkowski, prof. ucz., Uniwersytet Kardynała Stefana Wyszyńskiego w Warszawie, Wydział Nauk Pedagogicznych; e-mail: d.stepkowski@uksw.edu.pl.
} 
Schelera, lecz również dlatego że wynikają z niej interesujące implikacje dla współczesnego wychowania i kształcenia moralnego.

W rozwoju myślenia fenomenologicznego D. von Hildebranda prelegentka zwróciła uwagę na przyczynę rozejścia się jego drogi filozofowania i z drogą M. Schelera. Jej zdaniem, kluczowe znaczenie miała odmienna interpretacja słynnej metafory jaskini Platona. Przygotowując rozprawę doktorską, D. von Hildebrand uznał, że niewystarczające jest przyjęcie przedmiotów ukazujących się kajdaniarzom na ścianie jako źródłowych, lecz założył, że wraz z pojawianiem się na ścianie jaskini dane jest coś jeszcze, a mianowicie rozdzielenie (gr. chorismos). Jednym z przejawów tego zjawiska jest rozróżnienie mowy i myślenia - nie są one tożsame. Ta właściwość stała się dla D. von Hildebranda podstawą do stworzenia koncepcji wartości, która całkowicie odbiega od Schelerowskiej. W ujęciu pierwszego badacza wartość nie wiąże się głównie z oceną emocjonalną, lecz jest tym, co jawi się podmiotowi bezpośrednio $\mathrm{w}$ związku $\mathrm{z}$ rozpoznaniem przedmiotu i co oddziałuje na podmiot jako bezwzględne wezwanie. Głos wartości niejako zmusza podmiot do określonego zachowania, ale poprzedza go wysiłek skierowany na rozpoznanie wartości. Konsekwencją zaś tego jest transcendowanie siebie samego przez działanie zgodne z wartością.

Odnosząc zrekonstruowaną koncepcję D. von Hildebranda do edukacji moralnej, G. D’Addelfio wyraziła nadzieję, że edukacja ta przestanie być odczytywana jako budowanie subiektywności rozumianej jako egocentryczne skupienie podmiotu na sobie samym i swoich odczuciach, i zacznie być rozumiana jako otwarcie na to, co umożliwia człowiekowi transcendowanie siebie.

Po dyskusji gospodarz zaprosił na przerwę kawową, a po niej odbyła się druga sesja. Złożyły się na nią dwa wystąpienia. Jako pierwszy zabrał głos Daniel Bruk $\mathrm{z}$ The Hebrew University w Jerozolimie (Izrael), który przedstawił referat pt. Monolingual doctrine in early Jewish settlement in Palestine and it's influence on Israel's language education today. Prelegent nakreślił najpierw sięgające przełomu XIX i XX wieku początki kształtowania się języka hebrajskiego jako nowoczesnego, który po II wojnie światowej został wprowadzony w Izraelu jako język państwowy. Następnie przedstawił proces rozpowszechniania się tego języka w nowym państwie żydowskim i trudności, na jakie do dziś dnia ten proces natrafia. Za kluczowe podejście w określeniu roli języka hebrajskiego D. Bruk uznał rewolucję wielokulturową, jaka dokonała się w latach 6o. XX wieku. To dzięki niej możliwy obecnie istniejący tzw. statyczny pluralizm. Polega on na tym, że w państwie Izrael dopuszcza się posługiwanie się różnymi językami, które jednakże nie mogą zastępować języka hebrajskiego.

Drugi referat przedstawiony w tej sesji wygłosili Stanisław Gałkowski i Paweł Kaźmierczak z Akademii Ignatianum w Krakowie. Jego tytuł brzmiał: Docility vs. jadedness. The basis of commitment in education. Osią ich rozważań było zestawienie dwóch fenomenów: „pouczalności”, rozumianej jako gotowość do przyjmowania pouczeń, i zjawiska Blasiertheit (pol. „zblazowanie”), które nazwał i opisał 
niemiecki socjolog kultury Georg Simmel w 1903 roku, w opublikowanym wówczas tekście pt. Mentalność mieszkańców wielkich miast. Upraszczając, można powiedzieć, że polega ono na braku zaangażowania i obojętności, co dość powszechnie można zauważyć wśród uczniów i studentów. Według Rorty’ego, taka postawa prowadzi do relatywizmu moralnego, ponieważ podważa ona wiarę w autorytet i gotowość do powierzenia się mu. Prelegenci nie dali w swoim wystąpieniu odpowiedzi na pytanie, jak zachęcić młodych ludzi do zaangażowania się we własne kształcenie. Ich zdaniem „zblazowanie” jest jedną z ważniejszych przyczyn obecnego kryzysu nauczania i uczenia się.

Jak zwykle po referacie odbyła się dyskusja. Po niej zaproszono uczestników na lunch, a następnie odbyła się trzecia sesja tematyczne. Zaprezentowano w niej znowu dwa referaty. Pierwszy przedstawił Alberto Sánchez-Rojo z The Complutense University w Madrycie (Hiszpania). Tytuł wystąpienia brzmiał: The ethical value of learning to wait. Going back to Herbarts's educational theory. Prelegent rozpoczą od uwagi, że słowo „oczekiwać” wzbudza najczęściej negatywne skojarzenia. Oznacza bowiem niemożność osiągnięcia czegoś. W tym kontekście dokonał rozróżnienia dwu wyrazów w języku angielskim, stosowanych do wyrażania oczekiwania expect i wait. Pierwszy wyraz dotyczy oczekiwania czegoś konkretnego, drugi nie ma konotacji teleologicznej i oznacza raczej nastawienie.

Po tych rozróżnieniach terminologicznych A. Sánchez-Rojo omówił, jaką funkcję pełni termin „oczekiwanie” (wait) w koncepcji pedagogicznej Herbarta. Jego zdaniem koncepcja ta napotyka na duże trudności również $\mathrm{z}$ powodu innego współcześnie podejścia do zjawiska czasu. Czekanie odmierzane czasem nie jest tym czekaniem, o które chodzi w kształceniu. Jest ono postawą, dzięki której uczący się oczekuje dalszego kroku w procesie kształcenia, ale nie zasadzie osiągnięcie czegoś, co sprawia, że zaprzestaje działania, lecz właśnie inicjowania następnych kroków. Kształcenie szkolne, utożsamiane z transmisją wiedzy, unicestwia właściwie oczekiwanie w Herbartowskim sensie tego słowa.

Drugim prelegentem w tej sesji był Marcin Rebes z Uniwersytetu Jagiellońskiego $\mathrm{w}$ Krakowie. Swój referat zatytułował on: The role of the principle and experience of solidarity in modern society. An educational perspective.

Po kolejnej przerwie rozpoczęła się czwarta sesja. W niej jako pierwszy głos zabrała Arleta Suwalska z Uniwersytetu Łódzkiego, która przedstawiła temat: The subject of ethics in National Core Curriculum for general upper secondary schools 2015 in Finland. Na podstawie przeprowadzonych analiz, które przedstawiła w swojej rozprawy doktorskiej, przekonywała, że źródłem sukcesu fińskiego systemu edukacyjnego jest wcielenie w życie idei edukacyjnych rozwijanych w minionym stuleciu, a zasygnalizowanych w międzynarodowych dokumentach poświęconych problemowi kształcenia, takich jak: nauczanie zindywidualizowane, kooperacja, zaufanie, myślenie krytyczne, rozwiązywanie problemów itp.

Zgodnie ze zwyczajem po tym wystąpieniu oddano głos drugiemu prelegentowi. Był nim Jan Rutkowski z Uniwersytetu Warszawskiego. Tytuł jego wystąpienia 
brzmiał: Usefulness of modern science and education. Wychodząc od konstatacji, że nauka stanowi istotę kultury zachodnio-europejskiej i północno-amerykańskiej, prelegent rozważył związek zachodzący między filozofią i nauką w starożytności a w czasach współczesnych. Na tej podstawie poddał krytyce dominującą dziś tendencję do poszukiwania w wiedzy przede wszystkim użyteczności. Jego zdaniem, szkodzi ona nie tylko filozofii, lecz także naukom pozytywnym, których rola redukowana jest do dostarczania narzędzi do nowoczesnego postępu technologicznego.

Po ostatniej tego dnia przerwie na kawę rozpoczęła się piąta sesja, a w niej kolejne dwa referaty. Pierwszy wygłosił Nicholas Burbules z University of Illinois w Urbana-Champaigne (USA). Swój referat autor zatytułował The practice of virtue. Za Alasdairem MacIntyrem zaapelował on o ponowne odkrycie cnót. Żeby teoria cnoty mogła przerodzić się w praktykę, zaprezentował pięć zasad, Wszystkie one zostały skonstruowane według zbieżnego rozumowania, a mianowicie zachęty do zmiany w perspektywie patrzenia: (1) z uniwersalistycznej na prospołeczną; (2) z indywidualistycznej na wspólnotową; (3) z teoretycznej na praktyczną; (4) z instrumentalnej na pragmatyczną i (5) z ekskluzyjnej na inkluzyjną. Rozważania teoretyczne zilustrował przykładem nowoczesnego odczytania, czym jest cnota uczciwości (ang. honesty). Interesująca była uwaga N. Burbulesa odnośnie istoty filozofii wychowania. Jego zdaniem nie należy jej rozumieć jako aplikacji teorii filozoficznych do problemów pedagogicznych, lecz odczytanie pedagogicznego wymiaru kwestii filozoficznych.

Pierwszy dzień zakończyło spotkanie doktorantów uczestniczących konferencji.

Obrady wznowiono następnego dnia o godz. 10. Tak samo jak w poprzednim dniu odbyło się pięć sesji tematycznych, złożonych każdorazowo z dwóch referatów, dyskusji i przerwy. W szóstej sesji jako pierwszą poproszono o zabranie głosu Tanię Alonso-Sainz z The Autonomous University w Madrycie (Hiszpania). Tytuł jej wystąpienia brzmiał: Teachers as strong evaluators: an approach from Charles Taylor. Biorąc za punkt wyjścia niedawno sformułowany zarzut przeciwko teoretykom, w szczególności filozofom edukacji, zgodnie z którym nie mają oni doświadczenia praktycznego w pracy z dziećmi i młodzieżą, prelegentka rozważyła kwestię zależności między praktyką i teorią pedagogiczną. W drugiej części swojego wystąpienia, odwołując się do Charlesa Taylora, scharakteryzowała nastawienie naturalistyczne wobec danych empirycznych, i przeciwstawiła je postawie ewaluatora, któremu przypisała atrybut „silny” (ang. strong). W ten sposób T. Alonso-Sainz wskazała na potrzebę kształtowania u nauczycieli umiejętności rozumienia i wartościowania danych empirycznych uzyskiwanych $\mathrm{z}$ różnorodnych pomiarów efektywności ich pracy. Od tego zależy jej zdaniem trafność wyciąganych wniosków praktycznych.

Drugi referat w ten sesji - Good and evil as explanatory concepts in educational program - przedstawiła Joanna Górnicka-Kalinowska z Uniwersytetu Warszawskiego. Prelegentka osnową swoich rozważań uczyniła kwestię tego, czy i w jakim zakresie koncepcje zła mogą być przedmiotem wychowania i kształcenia moralnego. W związku z tym scharakteryzowała różnorakie teorie filozoficzne 
i niefilozoficzne zła i jego rozumienia, wskazując na ich złożoność i problematyczność w kontekście edukacyjnym. Pytanie, czy i jak można je zastosować w edukacji, pozostało właściwie bez satysfakcjonującej odpowiedzi.

Po przerwie na kawę odbyła się siódma sesja, w której przedstawiony został tylko jeden referat. Prelegentem był niżej podpisany. Tytuł wystąpienia brzmiał: A concept of a self-logical normativity of education and their relation to other normativity claims. Autorem referatu był Dietrich Benner, który z ważnych powodów osobistych nie mógł przybyć do Warszawy. Przedmiotem referatu było rozróżnienie między działaniem pedagogicznym i właściwą mu normatywnością a innymi rodzajami ludzkiego działania, którym również przysługuje odpowiednia normatywność. Jako przykład ilustrujący to rozróżnienie został omówiony film dokumentalny pt. Elternschule (pol. Szkoła dla rodziców). W filmie tym przedstawiono interwencje terapeutyczne nakierowane na dzieci, które wskutek błędów wychowawczych rodziców nie osiągnęły samosterowności i nie są zdolne wydobyć się z tego stanu o własnych siłach.

Następną sesję poprzedziła kolejna przerwa na kawę. Zgromadzeni wysłuchali $\mathrm{w}$ niej referatu wygłoszonego przez Stefaana Cuypersa $\mathrm{z}$ Catholic University of Leuven (Belgia), zatytułowanego R.S. Peters' philosophy of moral education in relation to his Freudian psychology. Z wnikliwością i znawstwem autor zapoznał zebranych z niuansami teorii edukacji liberalnej R.S. Petersa, którego postać zainteresowała badacza nie tylko ze względów zawodowych, lecz także osobowych.

Po tym gospodarz konferencji zaprosił zebranych na obiad. Następnie przystąpiono do kolejnej sesji. Najpierw głos zabrała Ursula Blythe z Kings College w Londynie (Wielka Brytania). Tytuł jej referatu brzmiał Cross-cultural education: a philosophical critique of Mencius's argument for human nature. Zafascynowana Chinami U. Blythe przekazała słuchaczom kilka swoich spostrzeżeń odnośnie mało znanej w szerszych kręgach społecznych myśli wielkich chińskich filozofów Konfucjusza i Mencjusza.

Po niej do przysłowiowej mównicy została poproszona Anouk Zuurmond z University of Groningen (Holandia), która przedstawiła referat pt. Ayn Rand and the educational values of objectivism. Wymieniona w tytule referatu twórczyni filozofii obiektywizmu zainteresowała A. Zuurmond jako autorka dwóch powieści - Źródło (1943) i Atlas zbuntowany (1957). Dla obu wspólnym motywem wydaje się być obiektywistyczna krytyka edukacji prowadzonej przez pedagogów, którzy „zapomnieli”, że kiedyś sami byli dziećmi. To zapomnienie powoduje, że przypisują sobie kompetencje i wiedzę, które nie tolerują żadnego sprzeciwu, a jedynie ślepą subordynację.

Do ostatniej, 10. sesji, przystąpiono po krótkiej przerwie. Na początku referat zaprezentował Piotr Warych z Wyższej Szkoły Pedagogiki i Administracji im. Mieszka I w Poznaniu. Tytuł wystąpienia brzmiał: The concept of love and friendship and its importance in contemporary education. W scholastyczny sposób 
prelegent omówił greckie terminy odnoszące się do miłości, wskazując, że warte są one zastosowania we współczesnej edukacji.

Po nim głos zabrał Rafał Godoń z Uniwersytetu Warszawskiego, który podjął temat Ethical aspects of schooling. Creativity in teaching and learning. Przedmiotem wystąpienia był projekt pt. „Akademia sztuki myślenia”, który był realizowany w latach 2017-2019, we współpracy z wybranymi szkołami średnimi Warszawy. Jego celem było rozwinięcie u młodzieży kompetencji krytycznego myślenia. Uzyskane wyniki zachęcały, zdaniem R. Godonia, do podejmowania wysiłków przybliżania młodzieży dziedziny wiedzy, jaką jest filozofia.

Na zakończenie odbyła się krótka ceremonia zamknięcia konferencji. Główny jej organizator, R. Godoń, podziękował gościom za przybycie, a w imieniu tych ostatnich N. Burbules wyraził wdzięczność za serdeczną i naukową atmosferę podczas dwudniowych obrad. Kolejne spotkanie za dwa lata będzie już pierwszym małym jubileuszem - 10-lecia warszawskiej konferencji pt. „Ethics and Education”. 